\title{
LA ANTIPOESÍA Y EL BOOM LATINOAMERICANO
}

\author{
Ignacio Echevarría
}

La antipoesía hizo su entrada en sociedad unos diez años antes de que lo hiciera el boom latinoamericano, prácticamente en paralelo a la renovación de la prosa latinoamericana que en el fondo lo permitió. De hecho, este ensayo explora de qué modo las tensiones que gestaron aquella renovación son, en gran medida, las mismas que la antipoesía buscó resolver. Sin embargo, de acuerdo al autor, todo apunta a que la obra de Parra, como suele suceder con la poesía latinoamericana, llegó con sus respuestas algo más lejos.

Antipoetry made its way into society about ten years before the boom in Latin America, virtually parallel to the renovation of Latin American prose that basically allowed it to happen. In fact, this article explores how the tensions that led to that renovation are, to a great extent, the same tensions that antipoetry sought to overcome. However, according to the author, everything points to Parra's work taking things somewhat farther, like what usually occurs in Latin American poetry.

IGNACio ECHEVARRÍA (Barcelona, 1960). Realizó estudios de filología y trabaja desde hace décadas como editor literario, especializado en la edición de clásicos antiguos y modernos. Ha impulsado y cuidado, entre otras, las obras completas de autores como Franz Kafka, Juan Carlos Onetti y Nicanor Parra. Crítico, articulista y conferenciante, ha reunido parte de sus trabajos en Trayecto. Un recorrido crítico por la reciente narrativa española (2005) y Desvíos. Un recorrido crítico por la reciente narrativa latinoamericana (2007). Email: elpatoapresurado@gmail.com 
66 ealmente, yo me inicié como prosista", declaraba Nicanor Parra a Mario Benedetti en 1969. "En el año 1935, con Jorge Millas, Carlos Pedraza y otros compañeros de adolescencia, publicamos una revista [Revista Nueva] y en los dos primeros números (no llegamos al tercero) vienen algunos trabajos míos en prosa. El primero se titula Gato en el camino. Es un cuento; realmente un anticuento. No sé si lo has visto alguna vez [...] De modo que yo en realidad soy un prosista frustrado; empecé como prosista y después derivé hacia la poesía, claro que muy rápidamente"...

¿Un prosista frustrado? Por mucho que no quepa tomar en serio la afirmación, sí vale la pena, sirviéndose de ella, considerar por una vez las relaciones de la antipoesía con la prosa de su tiempo; es decir, cambiarla de escenario, y observarla en un contexto con el que no se la suele confrontar: el de los años de gestación del fenómeno literario sin duda más espectacular de la segunda mitad del siglo XX: el llamado boom de la narrativa latinoamericana.

En el primer número de Revista Nueva, además de "Gato en el camino", publicó Parra tres poemas —-"Ensueño", "Nostalgia" y "Silencio"- reunidos bajo el título común de "Sensaciones". Nada o muy poco en esos poemitas juveniles permite presentir, ni siquiera en germen, la posterior deriva de Parra como poeta. Sin embargo, "Gato en el camino" - que el propio Parra, como se ha visto, califica de "anticuento"- suele ser tomado como precedente remoto pero inequívoco de la antipoesía.

Parra ha contado con pormenores la consternación que aquel texto produjo no sólo entre los lectores de la revista, sino, ya antes de su aparición, en su amigo Jorge Millas, el director de la misma:

"Yo digo: 'Ésta es mi colaboración para la Revista Nueva'. Millas lo lee. 'No — dice—, esto no sirve. Tú te quieres reír de la revista. Tú tienes que escribir algo serio'. Yo ya estaba bastante sinvergüenzón: 'Qué seriedad, de qué seriedad me hablas, ¿de las filosofías tuyas? Esas son pamplinas. Olvídate de tus filosofías'. Millas empezó a sentirse cada vez más herido, y me expulsó de la revista. 'No tan sólo no se publica Gato en el camino, sino que tampoco se publican las Sensaciones.' 'Muy bien — le dije —, vamos a ver si no se van a publicar'. Me 
fui a hablar con Pedraza. 'Qué te parece —le dije—, léete este cuento'. 'Esto es una maravilla - me dijo-, una maravilla. Vamos a hablar con Millas'. Pedraza era muy lento y muy calmado. 'Oye, Millas - le dice-, estuve leyendo el cuento de Parra, Gato en el camino. Es un cuento sensacional, un trabajo macanudo'. 'Qué va a ser un trabajo macanudo', le dice Millas. En mi presencia todo esto. 'Así es que no se publica', le dice Pedraza. 'No, no se publica'. 'Entonces yo retiro mis dibujos, no se publican mis dibujos'. 'No se publican los dibujos, muy bien'. Nos fuimos e hicimos una alianza indestructible con Pedraza. Lo primero que me dijo: 'Ya es tiempo que te diga cómo son las cosas realmente. Tú eres más poeta que Millas, no te olvides, eres más poeta que Millas'. Yo me sentí pero lanzado al séptimo cielo. Estábamos en esto cuando apareció un embajador de Millas, Oporto, un inspector mayor que nosotros, estudiante de castellano, estaba metido en Gómez de la Serna, su astro, y nosotros, jóvenes iconoclastas, nos reíamos de eso [...] Dice: 'Millas ha cambiado de opinión y dice que vuelvan ustedes, que publica los dibujos y el cuento, pero él no responde de nada'. 'Muy bien - le decimos-, nosotros respondemos de lo que hacemos'. Se publica la revista y en el internado pasamos a la categoría de tontos, de locos, de genios, de todo un poco. Algunos nos daban crédito, otros no nos daban nada, pero de lo único que se habló fue de eso. Todavía hoy [1972] tú vas al internado, te encuentras con la gente de la época y tocas el tema: 'Ah, claro, el Gato en el camino, de Parra' [...] Les llamaba la atención el absurdo. Un cuento que para comenzar se llama Gato en el camino, un título bastante estrambótico [...] Bueno, en cuanto apareció esa historia yo pasé rápidamente a una categoría suprema. El tipo más discutido. 'Ahí va Parra'. 'Ése es el autor del Gato en el camino'. Algunos se acercaban a reírse un poco, pero con cordialidad también. Otros, así, medio asombrados. 'Este Parra es un plato, está loco, qué se ha imaginado de nosotros', decían. Pero el asunto es que pasé inmediatamente a un sitial de honor" (conversación con Leonidas Morales, mayo de 1970).

Así narrada, en la anécdota concurren no pocos de los rasgos que, década y media después, caracterizarán el "gesto" antipoético: osadía, espíritu de provocación, vocación polémica, asunción irónica del papel de loco, de payaso, deliberada búsqueda del escándalo y de la espectacularidad... 
"Gato en el camino" no fue una tentativa excepcional. En su conversación con Benedetti, Parra habla de "algunos aislados intentos prosísticos; deben ser una media docena de trabajos, semicuentos o casi cuentos". Uno de ellos es el publicado en el segundo y último número de Revista Nueva: "El ángel (Tragedia novelada)", que Parra describe como "un revoltijo padre de cosas, un desorden, pero de vez en cuando con relámpagos". Y añade: "En ese tiempo, me parece, había leído a Pirandello, concurría a algunos espectáculos, veía películas de la época. De manera que el espíritu de la cultura moderna de algún modo llegaba a mí" (conversación con Leonidas Morales).

De los otros "intentos prosísticos" de Parra sólo resta un cuento más: "Tomás o el ayudante del otoño", que apareció en el número 11 de Aurora de Chile, del 5 de junio de 1939. Se trata de un cuento mucho más lírico que los dos anteriores, marcado en mayor medida todavía por la impronta poderosa del surrealismo, por entonces muy presente en la cultura literaria chilena.

En todos estos primeros tanteos en prosa apuntan ya, en diverso grado, algunas de las líneas fundamentales que encontrarán cauce en la antipoesía, muy en particular el sesgo narrativo de su impulso lírico y su acusado sentido dramático. Aparte, claro está, del empleo de una lengua literaria poco infatuada, en cierto sentido "rebajada", deliberadamente "prosaica", entendido este adjetivo en su acepción más común, que tal vez sea también la más equívoca.

Al referirse a esos primerizos trabajos en prosa como "cuentos o semicuentos", Parra puntualiza durante su ya mencionada conversación con Benedetti: "En realidad, el cuento propiamente tal, yo no lo concibo, como tampoco concibo la novela propiamente tal. Me interesan más bien en su estado de bocetos, o de bichos más o menos informes; me interesa más un renacuajo que la rana completa; me interesa más el insecto a medio camino, que el insecto perfecto. Tal vez debido a eso no he persistido en el trabajo de la prosa, que es más coherente que el poético".

Palabras que conviene poner en relación con otras escritas mucho antes, en la declaración preliminar que antecedía a una selección de sus poemas en 13 poetas chilenos (1938-1948), antología de la nueva poesía chilena armada por Hugo Zambelli y publicada en 1948. Allí Parra, por entonces ya metido de lleno en la senda de lo que poco 
tiempo después él mismo bautizaría como antipoesía, afirmaba que "la función del artista consiste en expresar rigurosamente sus experiencias personales sin comentarios de ninguna especie", y proclamaba, rotundo: "Huyo instintivamente del juego de palabras. Mi mayor esfuerzo está permanentemente dirigido a reducirlas a un mínimo. Busco una poesía a base de 'hechos' y no de combinaciones o figuras literarias. En este sentido me siento más cerca del hombre de ciencia que es el novelista que del poeta en su acepción restringida". A lo que añadía: "Finalmente, estoy en contra de la forma afectada del lenguaje tradicional poético. El lenguaje periodístico de un Dostoievski, de un Kafka o de un Sartre, cuadra mejor con mi temperamento que las acrobacias verbales de un Góngora o de un 'modernista' tomado al azar'.

En la antología de Zambelli figuraban ya tres de los poemas más emblemáticos de los reunidos pocos años después en la tercera parte de Poemas y antipoemas (1954): "La trampa", "Los vicios del mundo moderno" y "La víbora”. El que Zambelli los antologara en 1948 permite sospechar que se cuentan entre los primeros antipoemas propiamente dichos, y de ello cabe deducir que, como sugiere la citada "declaración preliminar", los modelos de cierta prosa narrativa contemporánea tuvieron un ascendente importante en el nacimiento de la antipoesía.

En su excelente trabajo sobre "Parra y sus precursores", leído en 2012 en la cátedra Bolaño de la Universidad Diego Portales, Niall Binns especula con la posibilidad de que Parra leyera por vez primera a Kafka en inglés, durante su primera estancia en Estados Unidos, año 1943. Binns recuerda que la traducción que Borges hizo de La metamorfosis y de otros relatos de Kafka es de 1938, y que por los años cuarenta, no sólo gracias a Borges, Kafka "estaba en el aire”. En cualquier caso, su presencia — escribe Binns_ “ "se palpa en la antipoesía en la intensidad agobiante de las atmósferas, en los rasgos de antihéroe de los personajes, y en el humor". El mismo Parra, demostrando haber leído muy bien al autor de El proceso, declararía que "el hablante lírico de los antipoemas es pasivo, porque a él le ocurren cosas, no más; el sujeto es una especie de proyección del sujeto kafkiano, que es una hoja en la tormenta, una víctima”.

En la mencionada "declaración preliminar", Parra, como se ha visto, reúne los nombres de Kafka, Sartre y Dostoievski para destacar "el lenguaje periodístico" que a su juicio emplean los tres en sus nove- 
las, radicalmente opuesto a "la forma afectada del lenguaje tradicional poético", a "las acrobacias verbales de un Góngora o de un 'modernista' tomado al azar". Lo que determinaría el ascendiente de la prosa narrativa contemporánea sobre la antipoesía, pues, no sería tanto el elemento propiamente narrativo como, más bien, su "método" estilístico: funcional, objetivo, sujeto a los hechos, desprovisto de florituras; "científico", como Parra sugiere, con todas las connotaciones que el término tiene en su boca (pues nunca hay que olvidar que, como "hombre de ciencia", Parra estuvo desde muy pronto familiarizado con el lenguaje preciso, irreductible, de las matemáticas y de la física).

Si bien el periodismo y la novela contemporánea transmiten a la antipoesía, al menos en una primera etapa, algo de la narratividad inherente a ambos, su influencia sobre la misma la determina sobre todo su condición de géneros en prosa. Es la prosa narrativa y periodística, en oposición al lenguaje tradicional poético, la que tempranamente atrae a Parra, que reconoce en ella dos atributos que él mismo aspira a trasladar a su escritura poética: por un lado, su rigor expresivo, desentendido de todo alambicamiento; $\mathrm{y}$, por otro, su carácter coloquial.

Acerca de lo primero, no está de más recordar que, después de siglos de supremacía indiscutible de la poesía, en el siglo XVI —el mismo en que tiene lugar el surgimiento de la novela moderna- la prosa empezó a ganar terreno como forma de expresión más acorde con el tipo de imaginación y de pensamiento — con el tipo de individuo y de complejidad - que se venía abriendo paso desde el Renacimiento. Si el siglo XVIII ha podido ser bautizado como "el siglo de la prosa" se debe a que durante el mismo la fantasía científica y la filosofía racional se impusieron definitivamente, sirviéndose de la prosa como cauce idóneo para sus conquistas. Fundamentalmente denotativa, más analítica, menos ambigua y polisémica, la prosa científica e informativa — no así la llamada prosa literaria o poética - se mostraba especialmente apta para expresar el desarrollo más o menos complejo de los procesos especulativos, lógicos y dialécticos del pensamiento humano, y para hacerlo con ese rigor por el que Parra, él mismo científico, siente natural atracción. Una atracción para la que actúa de contrapeso, según se ha visto, la suspicacia que experimenta Parra ante el imperativo de coherencia y de exhaustividad que la escritura en prosa parece entrañar (y conviene aquí 
recordar que el término prosa, de origen latino, deriva al parecer de la palabra latina provorsa o proversa, que a su vez provendría del verbo provertere, "dirigir delante").

De distinto orden es el interés que pueda haber experimentado Parra en sus inicios por la prosa en cuanto forma de expresión más acorde con el registro coloquial. Entre las definiciones más comunes de la prosa se cuenta la que la describe como "forma ordinaria del lenguaje, no sometida a las leyes externas de la versificación ni del ritmo" (Fernando Lázaro Carreter). Definición que invita a recordar el célebre pasaje de El burgués gentilhombre, de Molière, en que Jourdain, el protagonista de la obra, exclama cuando su interlocutor, el Filósofo, le explica las diferencias entre verso y prosa: “¡Por vida de Dios! ¡Más de cuarenta años que hablo en prosa sin saberlo!...”.

Tiene interés traer a colación el pasaje entero, en el que Jourdain le pide a su amigo el Filósofo que le ayude a redactar una misiva destinada a la dama de la que está perdidamente enamorado:

JOURDAIN. Será una galantería, ¿verdad?

FILÓSOFO. Sin duda alguna. ¿Y son versos los que queréis escribirle?

JOURDAIN. No, no; nada de versos.

FILÓSOFO. ¿Preferís la prosa?

JOURDAIN. No. No quiero ni verso ni prosa.

FILÓSOFO. ¡Pues una cosa u otra ha de ser!

JOURDAIN. ¿Por qué?

FILÓSOFO. Por la sencilla razón, señor mío, de que no hay más que dos maneras de expresarse: en prosa o en verso.

JOURDAIN. ¿Conque no hay más que prosa o verso?

FILÓSOFO. Nada más. Y todo lo que no está en prosa está en verso; y todo lo que no está en verso, está en prosa.

JOURDAIN. Y cuando uno habla, ¿en qué habla?

FILÓSOFO. En prosa.

JOURDAIN. ¡Cómo! Cuando yo le digo a Nicolasa: "Tráeme las zapatillas" o "dame el gorro de dormir", ¿hablo en prosa?

FILÓSOFO. Sí, señor.

JOURDAIN. ¡Por vida de Dios! ¡Más de cuarenta años que hablo en prosa sin saberlo!... 
Pese a su carácter bufo, o precisamente gracias a él, el pasaje sirve muy bien para encuadrar la disyuntiva verso/prosa y, con ella, la de prosa/poesía (a la que subyace, a su vez, la de verso/poesía), determinante de los rumbos de la trayectoria de Parra.

Retrospectivamente, es fácil entender la temprana atracción que la prosa ejerció en Parra en cuanto reflejo del habla común. "Gato en el camino" evidencia un claro esfuerzo por escribir sin florituras, ciñéndose lo más posible al lenguaje corriente. Eso mismo es lo que Parra aprecia en "el lenguaje periodístico de un Dostoievski, de un Kafka o de un Sartre", y en el periodismo propiamente dicho. En "Tomás o el ayudante del otoño", sin embargo, cuento posterior a "Gato en el camino" (se publicó un año después, en 1939, también en la Revista Nueva, según va dicho), se percibe ya una evolución hacia lo que cabe entender por prosa literaria o artística, categoría de prosa tan alejada, en definitiva, del habla común como pueda estarlo el verso, dado que también ella suele quedar sometida a exigencias de ritmo, y echa mano de todo tipo de recursos estilísticos.

Puede que sea cierto que, como pretende el Filósofo de Molière, no haya "más que dos maneras de expresarse: en prosa o en verso". No lo es tanto que toda expresión hablada sea propiamente prosa ("Tráeme las zapatillas" o "Dame el gorro de dormir", de hecho, podrían ser versos —octosílabos, para más señas-). Y es menos cierto todavía que la escritura en prosa, en general, se corresponda con el habla, en la que deja su huella todo un repertorio de frases sin terminar, de impropiedades del lenguaje, de interjecciones y de apoyos gestuales. De hecho, ni siquiera se corresponde con la elocuencia: un discurso recogido taquigráficamente puede dar una página que se lea con provecho y hasta con gusto, pero sólo por excepción y a base de falsear las reglas del género y quizá defraudar las exigencias del auditorio será una buena página de prosa, ya se piense en la prosa literaria, en la artística o en la prosa analítica. Esta última, aun cuando no se sirve deliberadamente de procedimientos estilísticos especiales, suele entrañar una complejidad tan inaccesible al hablante común como los versos más esforzados.

En el largo recorrido que va desde las colaboraciones en Revista Nueva (años 1937-1938) hasta los primeros antipoemas (hacia 19451946) — período en el que publica, bajo la influencia de Federico García Lorca, Cancionero sin nombre (1938) y años después, ahora bajo la 
influencia de Walt Whitman, los Ejercicios respiratorios (1943), suscribiendo en el camino los postulados de la que él mismo llamará "poesía de la claridad"-, Parra parece haberse percatado intuitivamente tanto de la engañosa naturalidad de la prosa como de su también engañosa libertad. Necesitará sin embargo casi una década entera para encontrar el camino adecuado a sus inquietudes. En sus conversaciones con René de Costa, mantenidas en el otoño de 1987, Parra recuerda una vez más sus comienzos como prosista, y puntualiza: "Prefería partir de la prosa antes que de la poesía tradicional; después fue el habla”. Es su búsqueda de una lenguaje literario lo más cercano posible al habla de la calle lo que, tras haberlo acercado a la prosa, enseguida lo aparta de ella, empujándolo a experimentar en distintas direcciones antes de encontrar su propio camino. Primero fue la poesía popular y la búsqueda, a través de ella, de una poesía "espontánea", en oposición a la poesía "cerebral" que practicaban las vanguardias del momento. Luego sobrevino el impacto de Whitman: "Me impresionó esa soltura para escribir, que no se ceñía a una métrica estricta ni se ajustaba a un lenguaje poético convencional. Además, me interesaban esas pequeñas historias, esas narraciones que aparecen en Hojas de hierba. Ahí se me acabaron los romances estilo García Lorca" (conversación con Juan Andrés Piña). Whitman abonó el terreno en que se produjo el nuevo impacto que iba a trastocar una vez más los rumbos de Parra: la lectura de Kafka y su "humor metafísico". "Ahí entonces empecé a articularme por dentro, a procesar todo eso. Comencé a escribir poemas como 'La víbora' y 'La trampa", (ibídem). A continuación tuvo lugar la larga estadía de Parra en Oxford (1949-1951) y el descubrimiento tanto de la vieja como de la nueva poesía anglosajona: Shakespeare, los metafísicos, William Blake, pero sobre todo Ezra Pound, T.S. Eliot, W. H. Auden, con su extraordinaria panoplia de recursos destinados a renovar la lengua poética, dejándola penetrar por la lengua coloquial.

A lo largo de todo este recorrido, no deja de actuar sobre Parra una influencia fundamental y constante en toda su trayectoria: el lenguaje de la física. "Creo que está presente en todo lo que escribo", declara Parra a Juan Andrés Piña, a quien le explica cómo "un poema tiene que ser un teorema: economía de lenguaje y economía de recursos: obtener lo máximo con lo mínimo". 
Se va viendo que el episódico coqueteo de Parra con la prosa, muy al comienzo de su trayectoria, conlleva sobre todo un rechazo de la artificiosidad de la poesía tradicional, siempre en nombre de la naturalidad del lenguaje hablado. Muy pronto, sin embargo, comprende Parra que, pese a las apariencias, este último tiene muy poco que ver con la prosa, para la que lo indispone, por otro lado, su natural tendencia a la concisión, a la brevedad. De modo que Parra prolonga su búsqueda en el marco de lo que se entiende convencionalmente por poema, experimentando gradualmente con el verso como herramienta con la que atrapar los ritmos y las cadencias del habla corriente. Y si bien al comienzo se muestra todavía muy mediado por las formas métricas tradicionales (el octosílabo, el endecasílabo, alternado más adelante con el heptasílabo), él mismo admite que el hecho de haber leído sólo superficialmente en su juventud a Rubén Darío lo libró de quedar atrapado por su música, por su sonsonete, de forma que le fue posible, no sin esfuerzo, sustraerse a sus dictados, rompiendo primero con todo tipo de sujeción (caso límite: los artefactos, sobre los que volveremos), y dando más adelante con lo que el mismo Parra denomina "endecasílabo libre", es decir, "un endecasílabo elástico, que se alarga y se acorta" (conversación con René de Costa).

Preguntado por René de Costa acerca de esto último, explica Parra: "Lo que se conserva en un poema escrito por endecasílabos libres es el perfil... El verso que predomina es el endecasílabo, exactamente. Pero si tú miras con cuidado, vas a ver que algunos versos son de doce sílabas, y otros de diez, y otros pueden ser de catorce, pero lo que da la pauta es el verso endecasílabo... Es una exigencia de la respiración, es una exigencia sintáctica también, de la conversación. Entonces, si tú lees el poema parece que fuera prosa, pero hay una estructura que se logra a base de endecasílabos libres, es decir, de endecasílabos que se alargan y se acortan" (subrayado mío).

En su conversación con René de Costa, Parra prolonga estas heterodoxas explicaciones abundando en la idea de que "el endecasílabo es el verso de la clase media". Y, después de considerar su peso y su presencia constante en la tradición poética en lengua castellana a partir de su implantación durante el Renacimiento, especula con la idea de que que se trate de una estructura fonética correspondiente a una determinada estructura psicológica, que a su vez se correspondería, en efecto, 
a la común entre las clases medias y cultivadas, de forma parecida a como el octosílabo viene a constituir una estructura fonética adecuada a la estructura psicológica de las clases populares. (Y aquí concurre una observación prodigada por Parra en múltiples ocasiones y relativa a la primera frase del Quijote: "En un lugar de la Mancha de cuyo nombre no quiero acordarme"; una frase en la que a un octosílabo - "En un lugar de la Mancha"- se superpone un endecasílabo - "de cuyo nombre no quiero acordarme"-, dos medidas de verso que se corresponderían, respectivamente, a la condición, estatus cultural y psicología de Sancho y de Alonso Quijano.)

Como sea, la práctica del por él llamado "endecasílabo libre" es una conquista relativamente tardía de Parra, quien sólo lo emplea desinhibidamente a partir de los Sermones y prédicas del Cristo de Elqui (1977). Antes, sin embargo, todas sus estrategias poéticas apuntan igualmente a una prosodia lo más cercana posible a la lengua conversacional. Con motivo de la publicación de Obra gruesa, en 1969, Ignacio Valente subrayaba el empeño de Parra por "escribir poemas que sean experiencias, que no traspongan la realidad en el juego de los espejos de la palabra, sino que la recubran tal cual en el lenguaje", y observaba cómo, con este objetivo, Parra acerca el lenguaje poético a la prosa "hasta un punto límite" ("algo bastante más amplio y profundo — añade el mismo Valente- que la mera y trillada utilización poética del habla coloquial, del "coloquialismo"').

Valente ha vuelto posteriormente a sondear las relaciones del antipoema y la prosa, conectando a aquél con la tendencia de una parte importante de la poesía contemporánea "a escribirse con el lenguaje del prosaísmo: a imitar el mecanismo aparente de la narración, de la crónica, del reportaje, de la epístola, del decir coloquial"; y ha advertido cómo, lejos de constituir una relajación de la exigencia poética, una rendición frente a los imperativos "de la prosa instrumental o del decir convencional", este rasgo de la antipoesía obedece a un proyecto de "purificación del dialecto de la tribu, mistificado hasta la banalidad en la juntura azarosa de palabras e imágenes, en la indeterminación de las metáforas caprichosas, en la sugerencia de profundidades que a menudo no existen o son inverificables en la objetividad del lenguaje".

Guiado por este objetivo, Parra exploró en primer lugar, como ya se ha dicho, los recursos de la poesía popular, a la que nunca dejó de 
prestar atención; pero no tardó en comprender que las formas tradicionales de la expresión popular resultaban arcaizantes en la medida en que iban quedando desplazadas por las manifestaciones propias de la cultura de masas. A este respecto, hacia finales de los años sesenta se produce un episodio fundamental en la antipoesía: el surgimiento de los llamados "artefactos", de los que Parra dice que vienen a constituir "la explosión del antipoema".

El mismo Parra ha definido en distintas ocasiones el artefacto como "una configuración lingüística autosuficiente, que se basta a sí misma", y ha aludido abiertamente a los modelos que lo inspiraron: los avisos publicitarios, los eslóganes políticos, las frases hechas del lenguaje corriente, los grafitis callejeros, las ocurrencias y obscenidades que llenan las paredes de los baños públicos. En todos estos casos, se trata de formulaciones muy elementales, que se sostienen sin necesidad de articularse con nada, al margen de todo discurso.

Los artefactos de Parra obvian la disyuntiva verso/prosa, que ya aparecía soslayada en antipoemas como "Frases", "Ideas sueltas" o "Telegramas", incluidos en Obra gruesa, y que, por mucho que se ofrezcan seriados a modo de "composición", constituyen de hecho una yuxtaposición de frases prácticamente autónomas, es decir, de artefactos, en el sentido que Parra concede a este término.

He aquí, arrancadas de la "prosa" cotidiana (de la prosa de Monsieur Jourdain, por así llamarla), "configuraciones lingüísticas" que, descontextualizadas, adquieren un insospechado poder de interpelación. Parra ha comparado a los artefactos con los fragmentos de una granada. Cuando ésta explosiona, "los fragmentos salen disparados a altas velocidades, o sea, están dotados de un gran cantidad de energía y pueden atravesar entonces la capa exterior del lector" (conversación con Leonidas Morales). No otra es la intención de los artefactos: "Se trata de penetrar, de romper, de sacar al lector de su modorra y pincharlo" (ibídem).

Debido a la radicalidad de su procedimiento, el trabajo con los artefactos permite apreciar con particular nitidez el modo en que la antipoesía toma posición en relación con la prosa. Lo formulará muy explícitamente el propio Parra en uno de los Chistes parra desorientar a la policía poesía (1983): 
WHAT IS POETRY?

todo lo que se dice es poesía

todo lo que se escribe es prosa

todo lo que se mueve es poesía

lo que no cambia de lugar es prosa

Donde el término prosa admite ser intercambiado por el de verso toda vez que éste, olvidándose de sus orígenes, se manifiesta como "forma afectada del lenguaje tradicional poético". Donde la poesía se opone a la prosa no por su rechazo de lo que se entiende comúnmente por "prosaísmo" (una de las marcas características de la antipoesía), sino por cuanto, en relación al habla, la prosa es un género de madurez, es decir, una forma de expresión tardía, culta, ligada desde su origen a las técnicas de la escritura y de la lectura, y sometida en consecuencia a imperativos de estabilidad y coherencia que poco o nada tienen que ver con la irregularidad y vivacidad del lenguaje hablado.

Se ha aludido al comienzo al interés de considerar las relaciones de la antipoesía con la prosa de su tiempo, algo que reclamaba una reflexión previa sobre la relación de la antipoesía con la prosa en general. Es momento ahora de recordar algunas de las coordenadas literarias en que se produce, en 1954, la irrupción del volumen de Poemas y antipoemas, considerado con justa razón como acta de nacimiento de la antipoesía.

En 1954 se cumplían diez años de la publicación de Ficciones (1944), del argentino Jorge Luis Borges; cuatro de la publicación de La vida breve (1950), del uruguayo Juan Carlos Onetti; tres de Bestiario (1951), del argentino Julio Cortázar; apenas dos de Confabulario (1952), del mexicano Juan José Arreola, y solamente uno de Los pasos perdidos (1953), del cubano Alejo Carpentier. Del mismo año 1954 es El sueño de los héroes, de Adolfo Bioy Casares (argentino). Al año siguiente iba a aparecer Pedro Páramo (1955), del mexicano Juan Rulfo, y muy poco después Zama (1956), del argentino Antonio di Benedetto. 
De 1956 son también los Cuentos fríos de Virgilio Piñera (cubano); de 1957, Coronación, de José Donoso (chileno), y Operación masacre, de Rodolfo Walsh (argentino); y de 1958, Los ríos profundos, de José María Arguedas (peruano), y La región más transparente, de Carlos Fuentes (mexicano). Por no hablar de autores como Miguel Ángel Asturias (Guatemala), Roberto Arlt (Argentina), Leopoldo Marechal (Argentina) y Felisberto Hernández (Uruguay), que venían publicando ya desde los años veinte.

Aunque el término a quo del fenómeno conocido como boom de la narrativa latinoamericana se retrotrae, como mucho, al año 1962 (más generalmente, al año 1964), queda claro, aun a partir de una enumeración apresurada y más bien aleatoria como la que acaba de hacerse, que para entonces hacía al menos dos décadas que en todos los extremos del continente venía incubándose y desarrollándose, algo más que incipientemente, el proceso de modernización de la prosa literaria — en particular la narrativa - que iba a asombrar a todo el mundo en las décadas de los sesenta y de los setenta.

La "revolución" de la antipoesía, así, tiene por marco general —entre otros posibles - una radical y profunda renovación de la prosa en toda Latinoamérica. Una renovación anticipada -importa subrayarlopor los rumbos emprendidos décadas antes por la poesía. Pues, como escribiera Ángel Rama, "la poesía siempre ha cumplido una función pionera en Latinoamérica. La novela asume sus conquistas con cierta lentitud propia del género. Las invenciones poéticas serán asumidas por la novela desde los años veinte, pero la aceleración del proceso sólo ocurrirá en los años cuarenta. La distensión rítmica que alcanza la poesía al liberarse de las matrices convencionales, la acentuación de lo vivido particular a través de un lenguaje connotativo, el desprendimiento de los códigos socializados que apunta a su subjetivización, la recuperación de las napas íntimas del habla con su peculiar léxico y sintaxis, la irrupción de la imagen y la metáfora como cifras de una unificación del mundo, serán algunas de las aportaciones que la poesía transmite a la narrativa".

Al señalar esto, no cabe menoscabar un elemento que hasta cierto punto escapa al influjo de la poesía: el aliento épico — por así llamarlo- que, alcanzado cierto nivel de desarrollo, emerge en unas sociedades faltas aún de relatos que den cuenta de ellas, de su historia tanto 
como de su identidad y de los conflictos, las tensiones y las dinámicas que albergan. En una entrevista realizada en 1971, el novelista español Juan Benet manifestaba su convicción de que, "en general, la literatura sudamericana (y eso nos choca mucho a los españoles) históricamente tuvo una lírica antes que una épica". "En general", añadía Benet, "toda literatura europea parte de una épica, y antes del Renacimiento se transforma en una lírica. La épica ya no tiene nada que hacer después del descubrimiento de América". Sin embargo, "en Sudamérica ha pasado al revés: la literatura tuvo una lírica antes que otra cosa. Y sólo dos siglos después empieza a haber ahora una épica. Eso desfigura mucho la visión histórica del país. Un país que primero tiene una lírica y luego una épica, cronológicamente es un país que parece que no tiene historia. Y ahora, a mi modo de ver, la novela sudamericana está haciendo épica histórica. Son los casos de García Márquez y de Alejo Carpentier”.

Improvisadas en el transcurso de una entrevista, no hay que atribuir a estas declaraciones un rigor que ni tienen ni pretenden; basta con asomarse a la perspectiva tan sugeridora que abarcan, y que invita a especular, en relación a las palabras antes citadas de Ángel Rama, que hacia mediados del siglo XX la narrativa latinoamericana comenzó a emanciparse de la poesía por virtud, precisamente, de ese impulso épico al que Benet alude y que conviene relativizar, o más bien amplificar, en cuanto se relaciona con algo más que el pasado histórico y se extiende a los conflictos del presente.

Este impulso épico es por completo extraño a Nicanor Parra, quien, como se ha visto, se desentiende muy pronto de él, menos interesado por los relatos propiamente dichos que, como declaró a Benedetti, por "su estado de bocetos, o de bichos más o menos informes". No hay que dejarse engañar por el anecdotismo y la ya destacada narratividad de ciertos antipoemas, en particular los más tempranos, correspondientes a los años cuarenta y cincuenta. Si, después de un efímero titubeo inicial, Parra abandona resueltamente no sólo la prosa narrativa, sino la prosa en general, una de las razones determinantes, aparte de las ya apuntadas, es sin duda su escasa inclinación natural por la dimensión épica del discurso, con todo lo que conlleva. Algo que lo invalida incluso como consumidor él mismo de novelas y narraciones, según declara abiertamente durante su ya citada conversación con René de Costa. Allí confiesa no haber leído más de cincuenta páginas de Rayuela, ni siquiera de 
Cien años de soledad: "Leo treinta, cuarenta páginas, y me parece que ya conozco a fondo al autor y que no es necesario seguir insistiendo. Lo mismo me pasa con Cortázar; hasta con el propio Rulfo me ocurre una cosa así". El único narrador al que Parra dice haber frecuentado, hasta el extremo de haberlo leído "cuarenta veces con lupa", es - ya se sabe- Kafka. Ni siquiera los cuentos de Borges dejan de impacientarlo: "Creo que no están reducidos a su última expresión, creo que todavía se podría atornillar más eso", dice.

Con todo, Parra se muestra muy consciente del contexto en que está trabajando. Con motivo de una observación que René de Costa le hace sobre la afinidad de ciertos antipoemas con las Historias de cronopios y de famas, de Julio Cortázar, contesta: "Alguien escribió una vez un artículo que se llama 'Cortázar y Parra'. Bueno, necesariamente tiene que haber grados de parentescos, no tan solo con él, con Borges también, con Rulfo. Todos estamos respirando el mismo aire, puede haber puntos de contacto, no me opongo". Una idea en la que abunda poco después, en la misma conversación: "Yo dije anteriormente que no tiene nada de extraño que los escritores del siglo XX se parezcan entre sí y que haya puntos comunes [...] No me sorprende que se me pueda tildar de pariente de Borges o de Cortázar". El mismo Parra señala el parentesco posible de su poema "Sinfonía de cuna" con un cuento de García Márquez, y a propósito del célebre comienzo de Cien años de soledad dice que lo movió a recordar su poema "Se canta al mar", de la primera parte de Poemas y antipoemas, en que describe cómo su padre lo llevó un día, durante su infancia, a ver el mar por vez primera.

Encuadrar el desarrollo de la antipoesía en el marco de la prosa narrativa latinoamericana en los años de su espectacular renovación sólo tiene sentido considerándola, sobre todo, desde el punto de vista de la lengua empleada y de los recursos puestos a su servicio. $\mathrm{Y}$ al asumir este punto de vista se topa enseguida con la encrucijada fundamental del escritor latinoamericano: la que entraña la necesidad de optar por un idioma escrito o por un habla.

Es de nuevo Ángel Rama quien acierta a plantear esta cuestión con su característica lucidez:

Hay una sensación que parece indesarraigable del hombre culto hispanoamericano: la de que habla, aplica, se manifiesta, existe en un lenguaje que no ha inventado, y que, por lo mismo, no le 
pertenece íntegramente. Esa sensación no rige, en cambio, en el hombre común, especialmente en el hombre analfabeto cuyo único bien cultural es, justamente, el habla [...] El hombre culto, en Latinoamérica, sabe de la existencia de España, de la literatura española, sabe sobre todo de la existencia de la Real Academia, conoce desde la escuela la imposición de las normas de prosodia y sintaxis determinadas, en última instancia, por esa Real Academia, y a la vez tiene clara conciencia de que él es, idiomáticamente, un ser híbrido: tiene una expresión propia, íntima, familiar - la de la infancia, la del amor, la de la amistad - , que es distinta, a veces mucho, de la expresión pública — del aula, del tratamiento ceremonioso, de la escritura, del periódico-. Desde luego que toda lengua acepta distintos grados de intimidad y complicidad, y en todas ellas hay un gradual pasaje de lo socializado a lo privado, pero en el caso concreto del hombre culto americano, hispanoparlante, tenemos dos personalidades idiomáticas simultáneas y no siempre armónicas. Como no existe en América una importante línea de novela popular (la prosa popular, tan mal reconocida y coleccionada, se ha aplicado preferentemente al costumbrismo), como el género es obra de hombres cultos, este problema de la doble expresión lingüística se traslada, sin alteración sensible, a la novela.

Es en este contexto en el que cobra el máximo interés considerar la estrategia de la antipoesía y los dilemas a que ella misma hubo de enfrentarse. Dilemas relativos a esa diglosia característica de la sociedad latinoamericana, en la que al habla popular y cotidiana se superpuso una lengua pública y de aparato que impuso su artificiosidad a la escritura.

Parra se percató muy pronto que de lo que se trataba, da igual si en el plano de la escritura poética o novelística, del verso o de la prosa, era de obviar resueltamente la disyuntiva y optar de modo inequívoco por el habla común, por "la lengua de la tribu", la única en la que, a sus ojos al menos, el gesto poético cobra su pleno sentido. Pero, ¿cómo?

En el periodo en que se gesta e irrumpe la antipoesía, los modos en que se planteaba la cuestión quedaban lejos de manifestar la clarividencia con que Parra se enfrenta a ella. La dicotomía entre idioma escrito y habla se venía traduciendo, ya desde el siglo XIX, en la de "utilizar un ajeno lenguaje académico o utilizar una jerga popular provinciana”. El 
modernismo no escapó a esta alternativa, que persistió hasta bien entrada la segunda mitad del siglo XX, con ventaja notoria para la opción cultista y preciosista, dada la rigidez y la artificiosidad con que solían cumplirse los intentos de trasladar a la escritura los usos del habla o del dialecto popular, primero por parte del naturalismo finisecular y luego por parte del regionalismo o criollismo.

Como observa Ángel Rama, “en la renovación idiomática literaria, no siempre es la aportación popular la más fecunda. En la prosa americana, tanto el galicismo modernista como el anglicismo vanguardista fueron buenos aportes rítmicos, expresivos, transformadores. Ayudaron a enriquecer el caudal de la lengua y de la literatura y, sobre todo, su desarrollo, encabalgados en una concepción supranacional $-\mathrm{y}$, por lo tanto, hispanoamericana, o meramente hispánica - de la cultura". Y algo semejante cabía observar en relación con la lengua poética por las fechas en que Parra decidía su vocación.

La opción culta apostó ampliamente - $\mathrm{y}$ a menudo felizmentepor un cosmopolitismo que sin embargo se lastró en más de un caso con el arcaísmo lingüístico (con frecuencia disfrazado de exotismo) a que la empujaba su necesidad de encontrar una base segura para sus aventuras. El cuidado de la lengua tendió a repercutir negativamente, durante demasiado tiempo, tanto en la eficacia narrativa de los novelistas como en la autenticidad emocional de los poetas. En el extremo opuesto, el regionalismo del siglo XX convierte en su causa la reivindicación de las lenguas vernáculas y emprende "una verdadera carrera a la búsqueda del término popular o arrabalero característico, distinto, no registrado". Ángel Rama recuerda con ironía - con una mención especial a los criollistas chilenos, en particular a Mariano Latorre - que las novelas regionalistas solían ofrecerse "acompañadas de largos apéndices donde se explican las palabras usadas en el texto, y parecería que se ha roto la unidad idiomática del continente: la lectura de algunas de ellas es un verdadero acertijo para los propios hispanoparlantes". El defecto fundamental de estas novelas radicaba — siempre según Rama- en el escalón que se apreciaba "entre el personaje que hablaba en un particular galimatías criollista, y el autor, quien se situaba por encima de sus criaturas y al describir, al comentar, al narrar, hablaba desde su cátedra más o menos purista". 
En 1964, fecha en la que escribe estas palabras, Ángel Rama observa entre los novelistas contemporáneos indicios suficientes como para concluir que "el gran salto que, en materia lingüística, en esta línea de la utilización del habla espontánea y popular, se ha producido $-\mathrm{y}$ que corresponde ya a nuestro tiempo-, es aquel por el cual el escritor ha ingresado al mismo lenguaje de sus personajes, los ha asumido y desde ellos habla". Así ocurriría gracias a que el novelista "no sólo se confía en la expresividad articular de las criaturas narrativas, sino que dosifica sus regionalismos, establece un pacto más sabio que autoriza una comunicación posible con un lector no sólo nacional sino también universal (y por universal entiendo hispanohablante). Para ello ha debido abandonar la concepción de que la palabra, aislada, es la clave de la creación automática de la narrativa, y ha desplazado su interés a la sintaxis, a las estructuras rítmicas, ha debido concebir la lengua como devenir articulado en el tiempo, trabajando en definitiva con un criterio semántico más estricto".

Rama invoca en este punto los nombres de Juan Rulfo, de Augusto Roa Bastos y de José María Arguedas, sin duda tres de los autores fundamentales de la renovación de la prosa latinoamericana que precedió al estallido del boom, los dos últimos particularmente marcados por la necesidad en que se vieron de ingresar en el idioma español habiendo crecido en entornos en los que se hablaba lenguas indígenas (el guaraní y el quechua, respectivamente).

El caso es que la "revolución" antipoética se fragua contemporáneamente a esta mutación que Rama observa en la novelística latinoamericana mediado ya el siglo XX, a tal punto que - no sin importantes salvedades - cabe hilvanar los términos en que Rama la describe con algunos de los postulados implícitos en aquélla. Corroborando la ya mencionada observación de Rama relativa a la función pionera que la poesía siempre ha cumplido en Latinoamérica en relación con la novela, la clarividencia con que Parra enfrenta esa tarea de igualamiento entre el lenguaje del escritor y el de sus personajes (para el caso, el del hablante lírico y sus máscaras sucesivas) se adelanta en mucho a los planteamientos y a los logros — sin duda altísimos — de los novelistas mencionados, que por otra parte se cuentan entre los pocos sobre los que Parra ha expresado en alguna ocasión su interés y su admiración. 
A Juan Rulfo en particular dedicó Nicanor Parra el primero y quizá más importante de sus "discursos de sobremesa", el que se conoce como "Discurso de Guadalajara", también titulado "Mai Mai Peñi" (leído con motivo de la entrega del Primer Premio Internacional de Literatura Latinoamericana y del Caribe Juan Rulfo, concedido por la Universidad de Guadalajara al mismo Parra en el marco de la V Feria Internacional del Libro, inaugurada en esa ciudad el 29 de noviembre de 1991). Dice allí Parra (tramo XXV):

PARA EVITAR LA TRAMPA DEL VERSO

Los escritores suelen caer en la prosa

Que es un vicio tan tonto como el otro

Cosa que no ocurre con Rulfo

No se diga que Rulfo escribe en prosa

Y a continuación:

RULFO TIENE SOBRE LOS POETAS CONVENCIONALES

Incluidos los antipoetas

La ventaja

De no escribir jamás en verso

Ni siquiera en el verso llamado libre

Que es el + artificioso de todos

Según un gato llamado Ezra Pound

El que no se menea es vaca

Claro

porque la gente no habla en verso

No sé si me explico

Lo que quiero decir es otra cosa

Pronunciadas en una etapa ya muy avanzada de su evolución como antipoeta, estas palabras tienes un valor importante a la hora de esclarecer la posición de Parra en relación con la prosa de su tiempo. Ese pro- 
vocativo "Que no se diga que Rulfo escribe en prosa" no deja lugar a dudas sobre la noción que Parra se hace de ésta. En el mismo discurso, Parra se hace a sí mismo la siguiente pregunta: "Si admira tanto a Rulfo / Por qué no se escribe una novela?". A lo que se responde: "Porque como su nombre lo indica / La novela no-ve-la realidad / Salvo que sea Rulfo quien la escriba" (tramo XLIV). Contestación que, por debajo del juego de palabras que la inspira, abunda en la idea de que ni prosa ni verso consiguen dar cuenta de la realidad tan difícilmente aprehensible del habla.

El mismo género "antipoético" del "discurso de sobremesa" es un paso más —el último, de momento— de los muchos dados por Parra en dirección a una escritura híbrida que, si bien se dispone gráficamente en la página a modo de un poema, posee a los oídos del lector la cadencia natural del habla conversacional. Parra se sirve de Rulfo, precisamente, para sugerir que la novela bien puede servir de plataforma para ensayar esa escritura híbrida, a condición de subvertir el mecanismo de la prosa de forma semejante a como él mismo ha subvertido el del verso, con vistas a hacerla apta como portavoz del lenguaje de la tribu.

Ahora bien, Rulfo, como por su parte Arguedas (a quien Parra también homenajea, pasajeramente, en su "Discurso de Guadalajara"), trabaja en un registro idiomático ceñido a un entorno básicamente rural y más bien primitivo, hasta cierto punto intemporal, en que transcurren sus narraciones. En tanto que, por mucho que la materia prima de la que se sirve Parra sea, en primera instancia, el habla característica del huaso chileno, del roto chileno, la antipoesía trabaja - y así ocurre ya desde un comienzo - sobre un registro mucho más amplio, complejo y heterogéneo: el correspondiente al ciudadano común de la segunda mitad del siglo XX: un individuo sustancialmente urbano (aun si no habita en las grandes ciudades), cuyas conductas verbales, mentalidad y sentimentalidad se hallan en buena medida formateadas por las nuevas tecnologías y los medios de comunicación de masas.

En relación con la prosa narrativa que se escribe en Latinoamérica en los años cincuenta y sesenta, la función pionera de la antipoesía consiste sobre todo en esa espectacular ampliación del registro del habla que se aspira a captar mediante la escritura, con lo que ello conlleva de dar entrada a todo tipo de materiales heteróclitos. Se ha destacado en múltiples ocasiones la afinidad de la antipoesía con el arte y la 
literatura pop, y su sintonía con algunos de los rasgos caracterizadores de lo que no tardaría en denominarse postmodernidad. Y es precisamente con la vista puesta en esos rasgos cómo se percibe más nítidamente la posición avanzada que la antipoesía mantiene respecto de la prosa de su tiempo.

Si el fenómeno del boom es consecuencia de un largo y múltiple proceso de modernización de la prosa narrativa del continente, asociado al impulso épico que emerge de unas sociedades que buscan sus propias señas de identidad y, a través de ellas, su propio lugar en el mundo, la antipoesía anticipa la etapa siguiente: la literatura que había de surgir del proceso de adaptación de esas mismas sociedades al nuevo orden cultural derivado del capitalismo tardío, con sus efectos de masificación y globalización, el desvanecimiento de las diferencias entre campo y ciudad, y el peso creciente de la televisión y las telecomunicaciones.

Más que en los narradores canónicos del boom (ya se piense en los precursores: Borges, Onetti, Arguedas, Carpentier, Rulfo, etcétera; ya en los protagonistas indiscutibles del fenómeno: Vargas Llosa, Fuentes, García Márquez, etcétera), las marcas de la antipoesía se reconocen en los narradores que - como Manuel Puig en Argentina o como José Agustín en México- se desmarcan tanto del gran estilo como de los grandes relatos, y se adelantan a corrientes que habían de imponerse años después, por obra de las promociones inmediatamente posteriores a las del boom.

En un ambicioso estudio sobre la peculiar posición de "Parra entre la modernidad y la postmodernidad", Niall Binns cita unas palabras de Antonio Skármeta referidas a la narrativa de lo que se llama en ocasiones postboom —en la que se encuadraría la propia literatura de Skármeta-, de la que dice que "es vocacionalmente antipretenciosa, programáticamente anticultural, sensible a lo banal, y más que reordenadora del mundo en un sistema estético congruente de amplia perspectiva, simplemente presentadora de él". Según el propio Binns, los novelistas del postboom "aceptan el desorden y participan en el mundo no como héroes, sino como hombres comunes. Son anti-autoritarios, rebeldes (a diferencia de la búsqueda revolucionaria de sus padres modernos) [...] son, en palabras de Rama, 'francotiradores contra todos los poderes', que se dan plena cuenta de las limitaciones de sus perspectivas. Es por 
eso que su impugnación de los poderes, de los grandes relatos institucionalizados, no conduce a la creación de nuevos proyectos totalizadores". En sus novelas, "el narrador adopta el mismo lenguaje coloquial de sus personajes, y pierde su fría omnisciencia y capacidad abarcadora. Los narradores se dejan seducir por los lenguajes y ritmos impuestos por la radio, la televisión y el teléfono en la sociedad contemporánea, por las repeticiones y los juegos verbales de la canción popular".

Puede que Skármeta no constituya el ejemplo más radical de las actitudes que él mismo describe y que dieron lugar, en la órbita del postboom y en su misma franja generacional, a las propuestas de novelistas como los argentinos César Aira y Fogwill, que siguen emitiendo en la actualidad un poderoso magisterio entre las nuevas promociones de narradores.

Binns cita aún otras palabras de Skármeta: "Los nacidos alrededor de 1940 somos los primeros en América Latina en enfrentarnos masivamente con la elocuencia de los medios de comunicación de masas", y él mismo subraya el énfasis puesto por los miembros de esa generación en "el cine, la música rock, la televisión, el coche, la píldora anticonceptiva, el amor libre, las drogas, la grabadora y la fotocopiadora".

Pero todo esto quedaba anticipado desde mucho antes por la antipoesía de Parra, en la que los rasgos así descritos van aparejados, según se viene diciendo, a la voluntad de acompasamiento con la lengua hablada.

Se trata - conviene insistir en ello - de un empeño de naturaleza utópica que plantea un reto permanente, por cuanto entraña una tensión y una alerta constante por parte del escritor resuelto a abordarlo. La caracterización que hace Skármeta de la narrativa de su generación admite ser empleada casi al pie de la letra para buena parte de la narrativa de las generaciones posteriores, incluidas las más recientes. Manteniéndose en el marco de la narrativa chilena — a los efectos tan representativa como la de cualquier otra del continente-, autores como Alberto Fuguet (nacido en 1964), Rafael Gumucio (1970), Alejandro Zambra (1975) y Diego Zúñiga (1987), por señalar sólo algunos de los más conocidos y representativos, trabajan, cada uno a su manera, y guiados por intereses distintos, en una dirección semejante.

En un ensayo publicado en 2007 y titulado muy intencionadamente "De novela, ni hablar", Zambra volvía sobre el viejo problema de la 
lengua por la que tiene que optar el escritor latinoamericano, muy en particular el narrador latinoamericano, y a propósito de un pasaje de la escritora brasileña Clarice Lispector en el que ésta habla de la desconfianza que le suscita la facilidad con que a momentos escribe ella misma, comentaba:

Así somos en Chile: desconfiamos de la fluidez, de la facilidad de palabra, por eso tartamudeamos tanto. No es una crítica: es una descripción. Desconfiamos, también, de la escritura. Tartamudeamos, también, en la escritura. Un nítido divorcio persiste entre la lengua hablada y la lengua escrita: son muchas las palabras y las frases que, entre nosotros, se dicen pero no se escriben. Contra ese divorcio lucharon Gabriela Mistral, Nicanor Parra, Enrique Lihn o Gonzalo Millán; se atrevieron, cada uno a su modo, a escribir, a buscar un lenguaje chileno. Violeta Parra se atrevió a descubrirlo, a crearlo y, por si fuera poco, a cantarlo.

El gran secreto de la literatura chilena es ese abismo entre lo que se dice y lo que se escribe. Lo que Neruda inventó fue, en realidad, un balbuceo elegante, un fraseo literario que favorece el rodeo y la eterna divagación. La antipoesía nos salvó de esa retórica instantánea. La dirección que empieza con Parra sigue con Lihn y con Juan Luis Martínez, pero éstos son sólo nombres de una lista interminable. Con Juan Luis Martínez, de hecho, la poesía chilena abandonó el verso. Ahora son muy pocos los poetas chilenos que escriben verso. No sé si escriben en prosa, pero estoy seguro de que no escriben en verso. Los poetas chilenos olvidaron hace rato a Neruda. Pero los narradores chilenos escriben, escribimos adentro, como si la novela fuera, en realidad, el largo eco de un poema reprimido. Habría que encontrar, tal vez, el poema no escrito pero presente en las novelas chilenas. Habría que escribir el poema y algo más; algo que lo niegue.

Ese "algo que lo niegue" quizá fuera un antipoema. Sí, probablemente eso. "Novela sin novela; literatura sin literatura", añade Zambra. Y no es difícil detectar en esta consigna el espíritu con que Parra sembró la literatura entera del continente, lo mismo da si prosa o poesía, señalando en la dirección por la que todavía transita. 


\section{REFERENCIAS EMPLEADAS}

Todas las citas de textos de Nicanor Parra se dan conforme a la edición de sus obras completas, supervisada por el autor, asesorada y establecida por Niall Binns y al cuidado de Ignacio Echevarría, con la colaboración de Adán Méndez: Obras completas \& algo +, 2 vols., Barcelona: Galaxia Gutenberg - Círculo de Lectores, 2016 y 2011. Esta edición se presenta acompañada de una abundante anotación, frecuentemente consultada.

La conversación de Nicanor Parra con Mario Benedetti se publicó originalmente bajo el título "Nicanor Parra o el artefacto con laureles", en Marcha (Montevideo), el 17 de octubre de 1969, pp. 13-15, y fue posteriormente recogida en M. Benedetti, Los poetas comunicantes, Montevideo: Marcha, 1972.

La conversación de Leonidas Morales con Nicanor Parra tuvo lugar en mayo de 1970 y quedó recogida, junto a la transcripción de otras bastante posteriores, en Conversaciones con Nicanor Parra, volumen publicado originalmente en 1991 y recientemente reeditado por Ediciones Universidad Diego Portales, Santiago, 2104.

Tanto el texto de la conferencia "Parra y sus precursores" (2012) como el ensayo "Un vals en un montón de escombros. Parra entre la modernidad y la postmodernidad" (1999), los dos trabajos de Niall Binns citados se encuentran reunidos en Niall Binns, Nicanor Parra o el arte de la demolición, Valparaíso: Universidad de Valparaíso, 2014 (pp. 223-237 y 71-155, respectivamente).

Las conversaciones de René de Costa con Nicanor Parra se grabaron en Chicago en 1987 y, aún inéditas, están próximas a publicarse.

La conversación de Juan Andrés Piña con Nicanor Parra tuvo lugar entre diciembre de 1989 y abril de 1990 y quedó recogida en Conversaciones con la poesía chilena, volumen publicado originalmente en 1990 y recientemente reeditado por Ediciones Universidad Diego Portales, Santiago, 2007.

La reseña de Ignacio Valente sobre Obra gruesa, de Nicanor Parra, se publicó en El Mercurio el 1 de junio de 1969; el mismo Valente refundió el texto de esta reseña en el capítulo titulado "El antipoema y la prosa", perteneciente a un ensayo posterior publicado bajo su nombre real, José Miguel Ibáñez Langlois, Para leer a Parra, Santiago: El Mercurio - Aguilar, 2003. 
Las citas de Ángel Rama proceden de sus ensayos titulados "Diez problemas para el novelista latinoamericano" (1964), "La generación del medio siglo" (1973), "La formación de la novela latinoamericana" (1974), "Medio siglo de narrativa latinoamericana (1922-1972)", todos recogidos en Ángel Rama, La novela en América Latina. Panoramas 1920-1980, Santiago: Ediciones Universidad Alberto Hurtado, 2008 (pp. 43-114, 35-42, 29-34 y 115-226, respectivamente).

La entrevista a Juan Benet se la hizo Federico Campbell en 1971 y quedó recogida, bajo el título "Juan Benet o el azar", en F. Campbell, Infame turba, Barcelona: Lumen, 1971 (pp. 292-310).

Las citas de Antonio Skármeta se dan a través del ensayo de Niall Binns "Un vals en un montón de escombros...", arriba citado, pero proceden de la contribución de Skármeta al volumen colectivo Más allá del boom: literatura y mercado, coordinado por Ángel Rama y publicado en México por la editorial Marcha en 1981 (pp. 263-285).

El ensayo "De novela, ni hablar" (2007), de Alejandro Zambra, está recogido en el volumen No sé leer, ed. Andrés Braithwaite, Santiago: Ediciones Universidad Diego Portales, 2007. EP 